\title{
Platinum-gold nanoraspberries as effective photosensitizer in anticancer photothermal therapy
}

\author{
J. Depciuch ${ }^{*}$ (OD, M. Stec ${ }^{2}$, B. Klebowski ${ }^{1}$, J. Baran² and M. Parlinska-Wojtan ${ }^{1}$
}

\begin{abstract}
Background: New nanophotosensitizers for photothermal cancer therapy (PTT) are still sought. In this paper we propose fancy shaped, non agglomerated core/shell PtAu NRs nanoraspberries (PtAu NRs) as potential nanophotosensitizers in PTT.

Results: Light microscopy images of two colon cancer cell lines (SW480, SW620) showed, that the laser irradiation combined with PtAu NRs caused visible changes in the cell morphology. Fourier Transform InfraRed (FTIR) and Raman spectroscopies showed chemical changes in the DNA, phospholipids, lipids and protein structures caused by laser irradiation in the presence of PtAu NRs. The MTS assay showed $\sim 25 \%$ mortality of cancer cells due to the addition of PtAu NRs to the cell culture, while for laser irradiation combined with nanoparticles, the mortality of cancer cells increased to $65 \%$ for the $650 \mathrm{~nm}$ laser and to $60 \%$ for the $808 \mathrm{~nm}$ laser. The calculated photothermal conversion efficiency reached $62 \%$ and $51 \%$ for the $650 \mathrm{~nm}$ and $808 \mathrm{~nm}$ lasers, respectively.
\end{abstract}

Conclusions: PtAu NRs could be applied as effective light-absorbers in the PTT anticancer therapy.

Keywords: Platinum-gold nanoraspberries, Photosensitizers, Anticancer photothermal therapy

\section{Background}

Nowadays, dynamic growth of research in nanotechnology for biomedical applications is observed. The main reason, are unique properties of nanoparticles when compared with bulk materials [1]. The scale decrease significantly modifies structural, optical, mechanical and electrical properties of these materials. Moreover, nanoparticles, having sizes similar to biomolecules, can pass through the cell lipid bilayer, offering the opportunity to use NPs in biological systems [2]. Consequently, nanoparticles are used as imaging agents, drug delivery systems or radiosensitizers in proton, radiation and photothermal therapy (PTT) [3-5]. In PTT, nanoparticles are delivered to the tumor cells and subsequently exposed to light at the NPs resonant energy, causing synchronized oscillation of the NPs conduction-band

\footnotetext{
*Correspondence: joanna.depciuch@iff.edu.pl

${ }^{1}$ Institute of Nuclear Physics Polish Academy of Sciences, 31-342 Krakow, Poland

Full list of author information is available at the end of the article
}

electrons, what results in heat production [6]. Thus the temperature in the tumor increases causing cellular damage and subsequent tumor regression. However, to increase the efficiency of thermal irradiation, the NPs, which are used in PTT, must absorb electromagnetic waves with lengths in the range between 650 and $1064 \mathrm{~nm}$ [7]. One of the most studied nanoparticles used for enhancement of PTT are metallic nanoparticles, especially gold nanoparticles (Au NPs) or platinum nanoparticles (Pt NPs) [8]. Features like extensive surface-to-volume ratio, the possibilities for tailoring charge, hydrophilicity and functionalization by surface chemistry make Au NPs effective photosensitizers used in PTT [9]. The platinum ions from the Pt nanoparticles, in combination with Au NPs, could be used as anticancer therapeutics with an effect similar to cisplatin. Porcel et al. suggested that platinum nanoparticles could be used for the enhancement of radiosensitization [10-12]. This approach enables spatially-targeted chemical activation of prodrugs and has no precedent 
among the therapeutic strategies offered by metal nanostructures. Moreover, due to high extinction coefficients in the NIR region of Au NPs and Pt NPs, these nanostructures can be used in photothermal therapy [13]. Notwithstanding, we have to be careful with the use of gold nanoparticles in cancer therapies, because it is still unknown whether the toxic effects caused by nanoparticles are life-threatening. There are a lot of studies, which showed non-toxicity of NPs, as well as high number of publications showing a cytotoxic effect of nanoparticles on the cells. Pfaller et al. [14] investigated the immunotoxicity, cytotoxicity and also genotoxicity effects of Au NPs on human cells. They studied three concentration of Au NPs, starting from $5.5^{*} 10^{10}$ and reaching $5.5^{*} 10^{12} \mathrm{NPs} / \mathrm{mL}$ using several tests. The obtained results showed, that in all three concentrations, Au NPs were non-toxic. However, Miller et al. [15] showed, that Au NPs can accumulate in blood vessels and causing their damage. It is difficult to directly compare the results about toxicity effect of nanoparticles obtained by others authors, because they used different nanoparticles, synthesized by different methods and using different reagents, which also have influence on the toxicity of NPs [16]. Indeed, Schmid et al. [17] showed, that the physico-chemical properties of the NPs and their specific surface area are dominating the cytotoxic effect, while the added Au NPs concentration is less important.

In the present study, the novel approach, was the combination of Au NPs with Pt NPs for obtaining good photothermal properties. For this purpose, the fancy shaped core/shell PtAu NRs nanoraspberries (PtAu NRs) were synthesized and they photothermal efficiency was investigated using two $650 \mathrm{~nm}$ and $808 \mathrm{~nm}$ wavelengths. Moreover, complexes changes in the morphology, chemistry and viability of cells cultured with PtAu NRs and irradiated as well as non-irradiated by two wavelengths, were shown in this paper. The chemical changes were investigated by FTIR and Raman spectroscopy and this is the first time, when these two methods were used for the determination of changes in the chemical compositions of cells cultured with NPs and subjected to laser irradiation. Furthermore, in this work we showed the values of photothermal conversion efficiency for the nanoparticles composed of two elements.

\section{Materials and methods Synthesis of NRs Pt NPs synthesis}

$10 \mathrm{~mL}$ of aqueous solution of ascorbic acid $(0.1 \mathrm{M})$ was placed in a water bath with magnetic stirrer (400 rpm) and heated to $100{ }^{\circ} \mathrm{C}$. Then, $2 \mathrm{~mL}$ of aqueous solution of $\mathrm{H}_{2} \mathrm{PtCl}_{4}(0.02 \mathrm{M})$ was added into the above solution, turning the color of the solution to brown after $10 \mathrm{~min}$.

\section{PtAu nanoraspberries synthesis}

The PtAu nanoraspberries were prepared by mixing $3 \mathrm{~mL}$ of Pt NPs, $10 \mathrm{~mL}$ deionized water and $1 \mathrm{~mL}$ of solution of sodium citrate. The reaction mixture was put in a water bath with stirring $(260 \mathrm{rpm})$ and heated to $93{ }^{\circ} \mathrm{C}$. Then, $200 \mu \mathrm{L}$ of $\mathrm{HAuCl}_{4}$ solution was added and kept at $93{ }^{\circ} \mathrm{C}$ for $20 \mathrm{~min}$. The color of the solution changed into orange.

\section{TEM characterization}

Scanning transmission electron microscopy (STEM) combined with the high-angle annular dark-field detector (HAADF) operating in conventional and high-resolution modes, was used to analyze the morphology of the synthesized nanoparticles. The crystallographic structure was assessed by selected area electron diffraction (SAED) patterns obtained in the TEM mode. The chemical composition of the synthesized nanoparticles was analyzed by energy dispersive X-ray spectroscopy (EDS). The observations were performed on an aberration-corrected FEI Titan electron microscope operating at $300 \mathrm{kV}$ equipped with a FEG cathode. The EDS mappings were done using a FEI Talos TEM, operating at $200 \mathrm{kV}$, equipped with a FEG cathode and four in-column EDS detectors (Super EDS system). The particle size distribution was evaluated from the HRSTEM images taken from different areas of the TEM grids. For each sample, the diameter of 100 nanoparticles was measured.

\section{X-ray diffraction}

The phase composition of the obtained nanoparticles was analyzed with X-ray diffraction (XRD). The XRD measurements were performed on a two-circle laboratory diffractometer Panalytical X'Pert Pro using a $\mathrm{Cu}$ anode with $\lambda_{K \alpha 1}=1.5406 \AA$ and $\lambda_{K \alpha 2}=1.5444 \AA$ working at $40 \mathrm{kV}$ and $30 \mathrm{~mA}$. The nanoparticles were deposited onto a zero background holder, which was placed on a sample spinner. The data were collected in the range from 30 to $90^{\circ}$ (20) at room temperature. The patterns were analyzed using Rietveld refinement through the Fullprof software, while for peak fitting the Thompson-Cox-Hasting pseudo-Voigt profile function was used and the background was fitted by a 6 -coefficient polynomial function $[18,19]$.

\section{Laser devices and PTT simulation protocols}

The simulation of the PTT on colon cancer cells and colon cancer cells cultured with PtAu NRs were conducted by low-intensity LED lasers with 650 and $808 \mathrm{~nm}$ 
wavelengths. An adjustable power supply was connected to the setup to enable the control of the power output of the laser, which additionally was calibrated using a power meter. The intensity of the laser was set to $100 \mathrm{~mW} / \mathrm{cm}^{2}$ and the irradiation time was chosen to be $5 \mathrm{~min}$, based on preliminary experiments of cancer cell irradiation during different times. These results are presented in Additional file 1.

\section{Cell culture}

Colon cancer cell lines (SW480, SW620) were obtained due to courtesy of Prof. Caroline Dive, Paterson Institute for Cancer Research, University of Manchester. These cell lines were cultured in DMEM with high glucose content (Corning, NY, USA) at $37{ }^{\circ} \mathrm{C}$ in humidified atmosphere with $5 \% \mathrm{CO}_{2}$. All media were supplemented with $10 \%$ fetal bovine serum (FBS, Biowest, Nuaille, France) and gentamicin $(50 \mu \mathrm{g} / \mathrm{mL})$, (PAN-Biotech, Aidenbach, Germany). The cells were cultured by bi-weekly passages and were regularly tested for Mycoplasma sp. contamination by PCR-ELISA kit (Roche, Mannheim, Germany) according to the manufacturers' instruction.

\section{MTS assay}

The cytotoxic activity of PtAu nanoraspberries against human colon cancer cells (SW480 and SW620) was determined by using 3-(4,5-dimethylthiazol-2-yl)-5-(3carboxymethoxyphenyl)-2-(4-sulfophenyl)-2H-tetrazolium (MTS) assay (CellTiter $96^{\circledR}$ AQueous One Solution Cell Proliferation Assay, Promega, Madison, WI). Briefly, the cells were cultured in flat-bottom 96-well plates (Sarstedt, Numbrecht, Germany) at a density of $1 \times 10^{4} /$ well in DMEM medium containing 10\% FBS. After $24 \mathrm{~h}$, $20 \mu \mathrm{L}$ of PtAu NRs solution was added to the cells. After additional $24 \mathrm{~h}$ of culture, $20 \mu \mathrm{L}$ of MTS (CellTiter $96^{\circledR}$ Aqueous One Solution Cell Proliferation Assay, Promega) dye solution was added per well and incubated for $2 \mathrm{~h}$. The quantity of formazan product, directly proportional to the number of living cells in culture, was detected by absorbance measurement at $490 \mathrm{~nm}$ with a 96-well plate reader (Spark ${ }^{\circledR}$ Tecan, Mannedorf, Switzerland). SW480 and SW620 cancer cell lines cultured without PtAu NRs and without irradiation were used as control samples.

In the present study the following samples were investigated (Table 1).

\section{Light microscopy images of cells}

The images of cells at $100 \times$ magnification were taken using an optical microscope Olympus IX70 (Olympus Corporation, Tokyo, Japan).
Table 1 Investigated samples

\begin{tabular}{lll}
\hline Control & SW480 & sW620 \\
\hline Investigated samples & SW480+PtAu NRs & SW620+PtAu NRs \\
& SW480+laser 650 nm & SW620+laser \\
& and 808 nm & $650 \mathrm{~nm}$ and \\
& $808 \mathrm{~nm}$ \\
& SW480+PtAu & SW620+PtAu \\
NRs + laser 650 nm & NRs + laser \\
and 808 nm & $650 \mathrm{~nm}$ and \\
& & $808 \mathrm{~nm}$
\end{tabular}

\section{Cell preparation for FTIR and FT-Raman measurements}

For FTIR and FT-Raman spectra acquisition, the cells in $10^{8} / \mathrm{mL}$ concentration were centrifuged for $5 \mathrm{~min}$ at $3000 \mathrm{rpm}$. Subsequently, the cells were washed three times in isotonic solution $(\mathrm{NaCl}, 0.9 \%)$ to ensure a complete removal of trypsin and culture medium.

\section{FTIR spectroscopy}

The measurements were carried out on an EXCALIBUR FTS-3000 spectrometer at room temperature. All spectra were recorded by attenuated total reflection (ATR) with a $\mathrm{ZnSn}$ crystal. $0.5 \mathrm{~mL}$ of cell containing solution was deposited on the ATR ZnSn crystal. FTIR spectra were recorded between 4000 and $500 \mathrm{~cm}^{-1}$. Each spectrum was obtained by averaging 64 scans recorded at a resolution of $4 \mathrm{~cm}^{-1}$. Baseline correction and normalization of the obtained spectra were performed using the OPUS software.

\section{FT-Raman spectroscopy}

FT-Raman spectra were recorded using a Nicolet NXR 9650 FT-Raman Spectrometer equipped with an Nd:YAG laser $(1064 \mathrm{~nm})$ and a germanium detector. The measurements were performed in the range from 150 to $3.700 \mathrm{~cm}^{-1}$ with a laser power of $1 \mathrm{~W}$. Unfocused laser beam was used with a diameter of approximately $100 \mu \mathrm{m}$ and a spectral resolution of $8 \mathrm{~cm}^{-1}$. The Raman spectra were processed by the Omnic/Thermo Scientific software based on 128 scans.

\section{Statistical analysis}

The obtained MTS assay results are represented as the mean \pm SEM (the standard error of the mean). The quantitative results were finally compared with the $\mathrm{T}$ test. $\mathrm{p}$ value $<0.05$ was considered to be statistically significant. Moreover, to obtain the information about the spectra variation depending on the type of measured samples, PCA was performed. The PCA procedure was done based on the selected spectral regions between 800 and $1800 \mathrm{~cm}^{-1}$ using the Past 3.0 software. 


\section{Photothermal conversion efficiency of PtAu nanoraspberries}

For photothermal conversion measurements, $0.3 \mathrm{~mL}$ of PtAu nanoraspberries containing solution were introduced into glass cuvettes. The solutions were laser irradiated at $650 \mathrm{~nm}$ and $808 \mathrm{~nm}$ wavelengths, in order to study the wavelength dependent photothermal conversion. The temperature evolution was recorded by a digital multimeter connected to a small Pt-100 thermo-resistor located inside the cuvette. The PtAu NRs were irradiated for $5 \mathrm{~min}$. To apply the time constant method, we took into account that the time evolution of the temperature after the laser was switched off, can be described by the following equation:

$$
\eta=\frac{\left(c_{w} m_{w}+c_{n P t} m_{n P t}+c_{n A u} m_{n A u}\right) \Delta T}{I A \Delta t} * 100 \%
$$

where $c_{w}, c_{n P t}$ and $c_{n A u}$ are the specific heats of water, $\mathrm{Pt}$ and $\mathrm{Au}$, respectively; $m w, m n P t$ and $m n A u$ are the masses of water, $\mathrm{Pt}$ and $\mathrm{Au}$, respectively; $\Delta T$ is the temperature rise in the $\Delta t$ time interval, $A$ is the illumination area of the fluid in the experiment and $I$ is the laser incident power. Moreover, to obtain the information about the photothermal efficiency of the nanoparticles, the following equation was used:

$$
\begin{aligned}
\eta_{\mathrm{NRs}} & \\
= & \frac{\left(c_{w} m_{w}+c_{n P t} m_{n P t}+c_{n A u} m_{n A u}\right) \Delta T_{1}-c_{w} m_{w} \Delta T_{2}}{m_{n P t}+m_{n A u} \Delta t} \\
& * 100 \%
\end{aligned}
$$

where $\Delta T_{1}$ is the difference of the PtAu NRs solution temperature before and after laser irradiation, $\Delta T_{2}$ is a difference of the water solution temperature before and after laser irradiation.

\section{Results \\ Morphology and structure of PtAu NRs}

The morphology and the chemistry of PtAu NRs were studied by electron microscopy. In Fig. 1, a STEM HAADF image of two nanoparticles (Fig. 1a) with the corresponding EDX maps (Fig. 1b) of Pt (c) and $\mathrm{Au}$ (d) distribution are presented. The Pt and Au NPs can be distinguished due to the Z-contrast differences of the nanoparticles, which are arranged similarly to core/shell raspberry structures, with a dozen of gold nanoparticles surrounding individual Pt nanoparticles. The shapes of both Au and Pt NPs are spherical, however the surface of the gold NPs is smooth, while the surface of the Pt NPs is furry-like. A larger magnification STEM image of the Pt nanoparticle, Fig. 1a, reveals that it consists of $<5 \mathrm{~nm}$ small Pt NPs, which agglomerated into a spherical object. Furthermore, the size of Au NPs is around $10 \mathrm{~nm}$, while the size of the agglomerated Pt NPs is eight times larger. It is very important that Au NPs, core Pt NPs and also PtAu NRs had a uniform size distribution and did not agglomerate.

The structural information concerning the PtAu NRs was obtained from TEM selected area electron diffraction (SAED). The SAED pattern (Fig. 2a) confirms that the NRs have a crystalline structure. The rings on SAED (Fig. 2a) patterns could be attributed to the (111), (200), (220), (311) and (222) lattice planes of Au and Pt nanocrystals with face-centered cubic lattice [20]. Due to the large size of the Pt NPs (>140 nm), the SAED pattern should contain some spots, however it is formed of well-defined, continuous rings. This is related to the fact that the Pt NPs consist of an aggregation of small, $<5 \mathrm{~nm}$, NPs, which scatter the incident electron beam uniformly forming regular diffraction rings. These structural findings were confirmed by analysis of XRD standard Bragg reflections (Fig. 2b), which could be assigned to fcc gold and fcc platinum [20-22]. The calculated

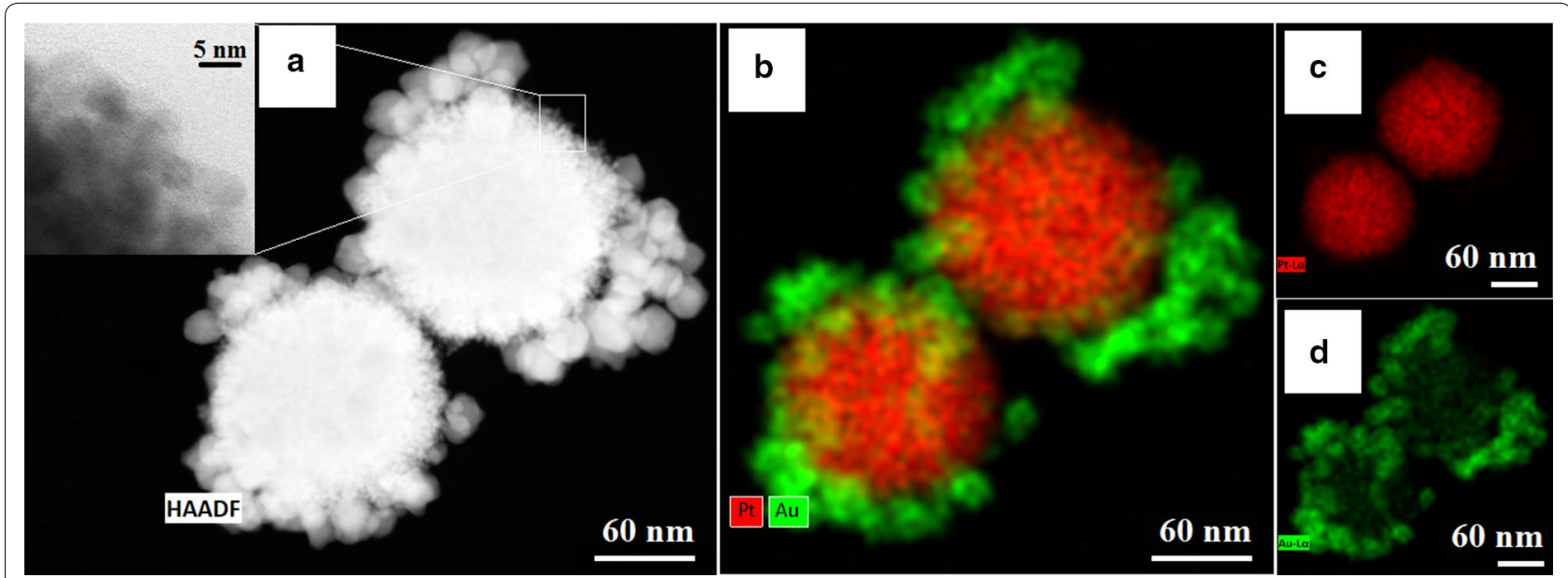

Fig. 1 STEM image of PtAu NRs (a); EDS distribution map of Pt and Au in the NRs (b); individual EDS distribution maps: Pt—green (c) and Au—red (d) distribution EDS maps 

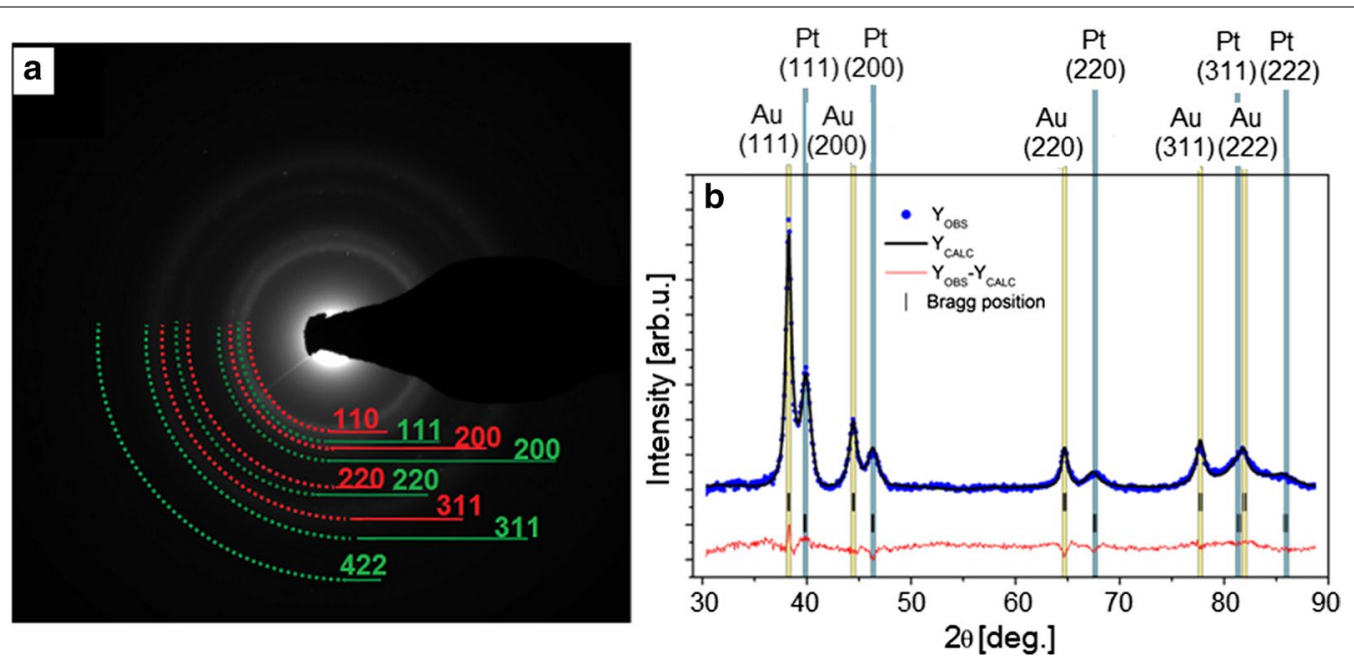

Fig. 2 SAED patterns of the PtAu NRs indexed with lattice parameters of Pt (red circles) and Au (green circles) (a);XRD recorded for PtAu NRs (b) The XRD pattern was refined with Rietveld method, where dots represent the experimental data, black line — the calculated plot, red line —-the difference between the observed and the calculated data. Tick marks show the positions of the allowed Bragg reflections

lattice constants $\left(\mathrm{a}_{\mathrm{Au}}=4.076 \AA\right.$ and $\mathrm{a}_{\mathrm{Pt}}=3.922 \AA$ with uncertainties $\sim 0.001 \AA$ ) were in a good agreement with lattice constants of $\mathrm{Au}$ and $\mathrm{Pt}$ nanoparticles known from the literature [23, 24]. In the present study, the fabricated nanoparticles consisted of two crystal phases (gold and platinum) and no alloy formation was identified by XRD. From TEM images it was found that Pt nanoparticles were a few times larger than the surrounding Au nanoparticles. Remembering that the Pt cores are composed of tiny nanoparticles, which aggregate into larger spherical objects, it is obvious that the full width at half-maximum (FWHM) of the peaks from the Pt phase is larger than the FWHM from Au shell. Thus the XRD patterns nicely confirm that the size of crystallites in platinum core was smaller than size of the Au NPs [25]. The average coherent scattering lengths $(\langle\mathrm{D}\rangle)$ for gold and platinum phases, which we assumed to be equal to crystallite sizes, were estimated in the framework of micro-structural analysis from Fullprof and were around $\left\langle\mathrm{D}_{\mathrm{Au}}\right\rangle \approx 10 \mathrm{~nm}$ and $\left\langle\mathrm{D}_{\mathrm{Pt}}\right\rangle \approx 5 \mathrm{~nm}$. In conclusion, TEM and XRD analysis evidenced that the fabricated PtAu nanoraspberries can be described as large agglomerates of small platinum crystallites forming the core, which are surrounded by wellcrystallized gold nanoparticles forming a non-continuous shell.

\section{Morphological, chemical and viability changes in cancer cells induced only by the addition of PtAu NRs and by irradiation with $650 \mathrm{~nm}$ and $808 \mathrm{~nm}$ lasers in the presence of PtAu NRs}

The obtained results showing morphological, chemical and viability changes in cancer cells caused by the addition of PtAu NRs, by irradiation with $650 \mathrm{~nm}$ and $808 \mathrm{~nm}$ lasers with and without PtAu NRs, were compared to control samples.

The microscopy images of SW480 and SW620 cell lines cultures, showed that PtAu NRs addition (Fig. 3a1, b1), as well as laser irradiation in nanoraspberries presence (Fig. 3a3, b3, a5, b5), caused morphological changes in the cells, when comparing the images with those of control samples, Fig. 3a, b, respectively. Moreover, it was noticed, that PtAu NRs combined with laser irradiation caused more damage to the cells than PtAu NRs addition, because in the latter case, a larger number of cells survived, which was observed as cells adhesion to the base. Conversely, irradiation of cells cultured without PtAu NRs by lasers caused no visible changes in the morphology of these cells (Fig. 3a2, b2, a4, b4), in comparison with the control. This observation confirms, that the irradiation time of $5 \mathrm{~min}$ was chosen adequately, as it was intended not to destroy the cancer cells. Moreover, light microscopy images of cells showed, that generally higher mortality of the investigated SW480 samples was observed, in comparison with investigated SW620 cell lines samples.

For the first time we showed the chemical changes in the cells occurring after the addition of PtAu NRs, as well as after laser irradiation in the presence of nanoparticles, which were investigated by FTIR (Fig. 4) and FTRaman (Fig. 5) spectroscopies. When we compare the FTIR (Fig. 4) and Raman (Fig. 5) spectra of cells cultured with PtAu NRs and irradiated by $650 \mathrm{~nm}$ and $808 \mathrm{~nm}$ lasers with spectra of control cells (grey spectra), differences in the values of maximum absorbances, as well as in the peak positions, were observed. Furthermore, in the Raman spectra absences of peaks were noticed in the 

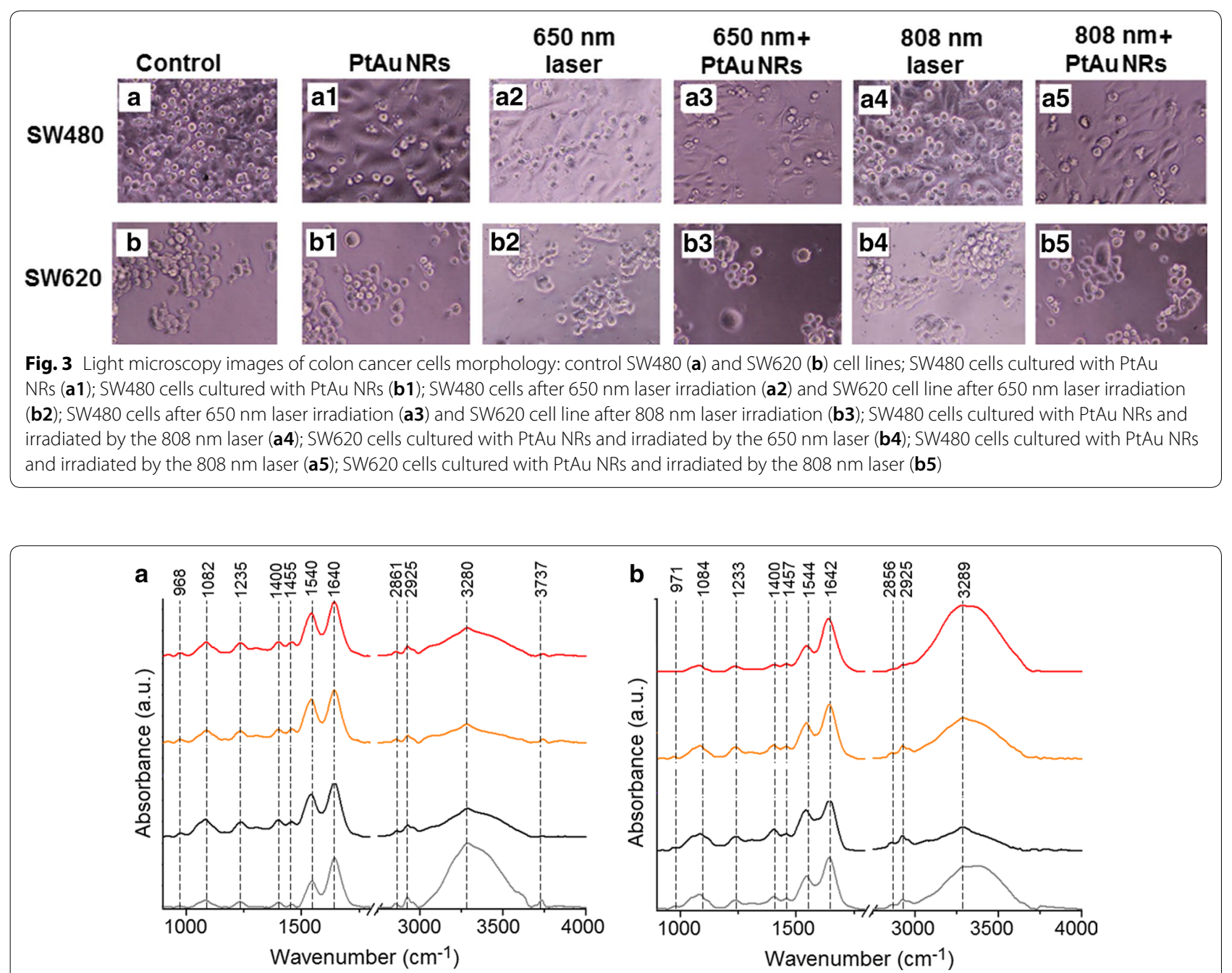

Fig. 4 FTIR spectra of SW480 (a), SW620 (b) colon cancer cell lines: control (grey spectrum); cells cultured with the PtAu NRs (black spectrum); cells cultured with the PtAu NRs and irradiated by the $650 \mathrm{~nm}$ laser (orange spectrum); cells cultured with the PtAu NRs and irradiated by the $808 \mathrm{~nm}$ laser (red spectrum)

cells cultured with nanoraspberries. The identified peaks for all the obtained FTIR and Raman spectra are presented in detail in Table 2.

All the obtained results for the SW480 cells were compared with control samples consisting of SW480, while the results obtained for the SW620 cells were compared with the SW620 cell line, respectively. In the FTIR spectra of both cell lines, the shift of the peak corresponding to the $\mathrm{PO}_{3}^{-2}$ group from DNA, RNA and phospholipids, was visible. Moreover, the addition of PtAu NRs to the cells and subsequent laser irradiation caused changes in the amide I structure and in $\mathrm{CH}_{3}$ asymmetric stretching lipids vibrations in the SW480 and SW620 cells. Moreover, in the SW480 cells cultured with PtAu NRs, a shift of the peak originating from the $\mathrm{C}-\mathrm{O}$ group from glycogen was induced by irradiation. A shift of the amide A peak was caused by the nanoraspberries addition to the SW620 cells and subsequent laser irradiation. Moreover, in cells with PtAu NRs irradiated using the $808 \mathrm{~nm}$ laser structural changes in the amide I were induced.

In the Raman spectra of both cell lines cultured with $\mathrm{PtAu}$ NRs irradiated and non-irradiated by $650 \mathrm{~nm}$ and $808 \mathrm{~nm}$ lasers, shift of peaks corresponding to the $\mathrm{C}-\mathrm{H}$ in-plane bending mode and the amide III were observed. Moreover, in the Raman spectra of the SW480 and SW620 cells cultured with PtAu NRs and irradiated as well as non-irradiated by lasers, structural changes in glucose, triglycerides, collagen and cholesterol, were noticed. In the case of the SW620 cells cultured with PtAu NRs and laser irradiated, shift of peaks 

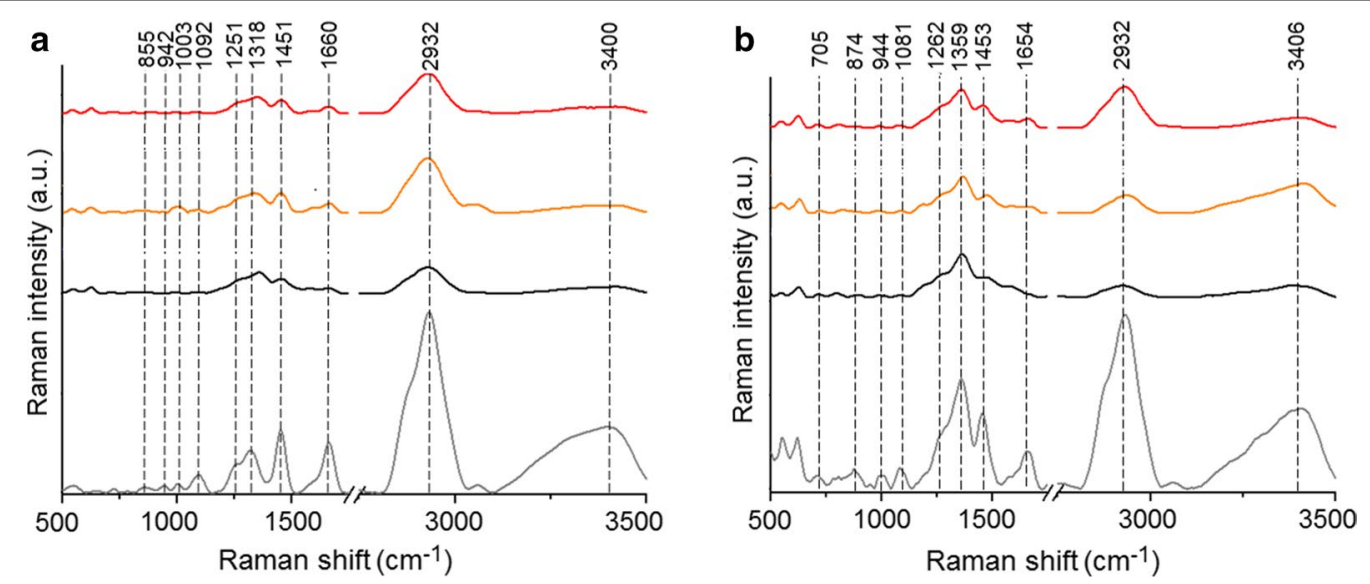

Fig. 5 FT-Raman spectra of SW480 (a), SW620 (b) colon cancer cells line: control (grey spectrum); cells cultured with the PtAu NRs (black spectrum); cells cultured with the PtAu NRs and irradiated by the $650 \mathrm{~nm}$ laser (orange spectrum); cells cultured with the PtAu NRs and irradiated by the $808 \mathrm{~nm}$ laser (red spectrum)

corresponding to $\mathrm{CH}_{2}$ fatty acid functional groups and amide I, were visible. Moreover, laser irradiation with PtAu NRs caused structural changes in SW620 cells in phenylalanine.

When we compare the FTIR and FT-Raman spectra obtained for the investigated samples and the control samples, differences in the structure and values of absorbance, as well as in the Raman intensities, were observed. However, when we compare spectra obtained for cells cultured with PtAu NRs and subjected to laser irradiation, the FTIR and FT-Raman results are similar. Therefore, to obtain information about the significant differences between the spectra, PCA analysis was performed and the results are presented in Fig. 6.

PCA analysis of FTIR and Raman spectra of both cell lines (Fig. 6) showed, that the data obtained for the control samples is located in a different quarter than the data obtained for other samples. It means that the chemical changes caused by PtAu NRs and laser irradiation combined with nanoparticles are statistically significant. Moreover, PCA analysis of FTIR data for the SW480 cell line (Fig. 6a) and of Raman data for both cell lines (Fig. 6c, d) showed that the PtAu NRs caused other chemical changes, than these obtained for cells with nanoparticles irradiated by lasers. Furthermore, PCA analysis of these samples (Fig. 6a, c, d) showed that laser irradiation in the presence of PtAu NRs caused similar chemical changes in the cells, regardless which laser wavelength was used. Only for the FTIR data obtained from the SW620 cell line (Fig. 6b), PCA analysis showed that laser irradiation with PtAu NRs caused similar chemical changes to these obtained for cells cultured with nanoparticles. Moreover, these changes were different when compared with the cells containing PtAu NRs irradiated by the $808 \mathrm{~nm}$ laser.

The MTS assay was used to determine the influence of nanoparticles addition to cells and laser irradiation with and without the presence of PtAu NRs on the viability of cancer cells, Fig. 7 .

Figure 7 shows the results of the MTS assay presented by mean \pm SEM percentage values of cells viability. Two combinations allowing the comparison of all samples was performed in: ${ }^{*} \mathrm{p}<0.05$ corresponding to the comparison with the control, and ${ }^{\#} \mathrm{p}<0.05$ corresponding to the comparison with the cells cultured with PtAu NRs. In Fig. 7, statistically significant differences between the investigated samples and the control groups were observed. Addition of the PtAu NRs to the cell cultures caused a $27 \%$ and $22 \%$ mortality of the SW 480 and the SW620 cells, respectively. Furthermore, not statistically significant changes in the viability of cells were observed for samples irradiated by the $650 \mathrm{~nm}$ and $808 \mathrm{~nm}$ lasers. However, adding PtAu NRs to cells cultures and subjecting these cells to laser irradiation caused an increase of mortality of the cancer cells. The $650 \mathrm{~nm}$ laser caused around $65 \%$ mortality of both cell lines, while the $808 \mathrm{~nm}$ laser caused $\sim 60 \%$ mortality of cells with PtAu NRs. However, a higher percentage of dead cells in the SW480 line was noticed. When we compare the mortality of cells cultured with PtAu NRs and irradiated by lasers, a $\sim 40 \%$ higher mortality in both cells lines, were observed for the $650 \mathrm{~nm}$ laser irradiated samples and $\sim 35 \%$ higher mortality when the $808 \mathrm{~nm}$ laser was used. 
Table 2 FTIR and Raman peaks positions in the analyzed samples with description of vibrations corresponding to the respective functional groups [26-41]

\begin{tabular}{|c|c|c|c|c|c|c|c|c|}
\hline SW480 & $\begin{array}{l}\text { SW480+PtAu } \\
\text { NRs }\end{array}$ & $\begin{array}{l}\text { SW480+PtAu } \\
\text { NRs }+650 \mathrm{~nm}\end{array}$ & $\begin{array}{l}\text { SW480+PtAu } \\
\text { NRs }+808 \mathrm{~nm}\end{array}$ & SW620 & $\begin{array}{l}\text { SW620+PtAu } \\
\text { NRs }\end{array}$ & $\begin{array}{l}\text { SW620+PtAu } \\
\text { NRs }+650 \mathrm{~nm}\end{array}$ & $\begin{array}{l}\text { SW620+PtAu } \\
\text { NRs }+808 \mathrm{~nm}\end{array}$ & Vibrations \\
\hline \multicolumn{9}{|c|}{ FTIR spectroscopy peaks $\left(\mathrm{cm}^{-1}\right)$} \\
\hline 968 & 971 & 974 & 974 & 977 & 974 & 971 & 970 & $\begin{array}{l}\mathrm{PO}_{3}^{-2} \text { group from DNA, RNA } \\
\text { and phospholipids }\end{array}$ \\
\hline 1082 & 1084 & 1087 & 1086 & 1083 & 1082 & 1084 & 1081 & C-O group from glycogen \\
\hline 1235 & 1236 & 1234 & 1235 & 1237 & 1236 & 1237 & 1235 & Amide III \\
\hline 1400 & 1402 & 1400 & 1400 & 1402 & 1402 & 1401 & 1403 & $\begin{array}{l}\mathrm{CH}_{2} \text { group from protein and } \\
\text { lipids }\end{array}$ \\
\hline 1455 & 1458 & 1458 & 1458 & 1458 & 1455 & 1456 & 1457 & $\mathrm{CH}_{2}$ group from cholesterol \\
\hline 1540 & 1545 & 1545 & 1546 & 1544 & 1534 & 1533 & 1534 & Amide II \\
\hline 1640 & 1641 & 1642 & 1642 & 1642 & 1641 & 1642 & 1638 & Amide I \\
\hline 2861 & 2860 & 2857 & 2858 & 2860 & 2862 & 2862 & 2864 & $\begin{array}{l}\text { Symmetric stretching vibra- } \\
\text { tions of } \mathrm{CH}_{2}\end{array}$ \\
\hline 2925 & 2928 & 2925 & 2926 & 2927 & 2927 & 2927 & 2928 & $\begin{array}{l}\text { Asymmetric stretching } \\
\text { vibrations of } \mathrm{CH}_{2}\end{array}$ \\
\hline 3280 & 3284 & 3289 & 3284 & 3296 & 3290 & 3288 & 3281 & $\mathrm{CH}_{3}$ asymmetric stretching \\
\hline 3737 & 3738 & 3739 & 3741 & 3756 & 3727 & 3726 & 3738 & $\begin{array}{l}\text { Amide } \mathrm{A} \text { and } \mathrm{OH} \text { group } \\
\text { from water }\end{array}$ \\
\hline \multicolumn{9}{|c|}{ Raman spectroscopy peaks $\left(\mathrm{cm}^{-1}\right)$} \\
\hline 711 & 706 & 715 & - & 715 & 713 & 724 & 706 & $\begin{array}{l}\mathrm{C}-\mathrm{H} \text { in-plane bending } \\
\text { mode }\end{array}$ \\
\hline 855 & 842 & 866 & 846 & 874 & 892 & 862 & 883 & $\begin{array}{l}\mathrm{C}-\mathrm{H} \text { in-plane bending } \\
\text { mode }\end{array}$ \\
\hline 942 & 950 & 947 & 943 & 943 & 941 & 981 & 983 & $\begin{array}{l}\mathrm{C}-\mathrm{H} \text { in-plane bending } \\
\text { mode of phenylalanine }\end{array}$ \\
\hline 1092 & 1078 & 1082 & 1078 & 1081 & 1074 & 1081 & 1075 & $\begin{array}{l}\text { Glucose, Triglycerides, C-C } \\
\text { (lipid) }\end{array}$ \\
\hline 1251 & 1283 & 1282 & 1285 & 1286 & 1278 & 1274 & 1275 & Amide III \\
\hline 1318 & 1341 & 1335 & 1350 & 1359 & 1362 & 1365 & 1359 & $\begin{array}{l}\mathrm{CH}_{3} / \mathrm{CH}_{2} \text { twisting or } \\
\text { bending mode of lipid/ } \\
\text { collagen }\end{array}$ \\
\hline 1451 & 1452 & 1451 & 1453 & 1453 & 1473 & 1467 & 1462 & $\begin{array}{l}\text { Fatty acids, } \mathrm{CH}_{2} \text { (lipids and } \\
\text { proteins) }\end{array}$ \\
\hline 1660 & 1661 & 1663 & 1661 & 1654 & 1691 & 1671 & 1663 & Amide I \\
\hline 2932 & 2929 & 2928 & 2930 & 2932 & 2927 & 2937 & 2929 & $\mathrm{CH}$ band of lipids \\
\hline 3400 & 3414 & 3420 & 3421 & 3417 & 3411 & 3416 & 3409 & $\begin{array}{l}\mathrm{CH} \text { from cholesterol and } \\
\text { cholesterol ester }\end{array}$ \\
\hline
\end{tabular}

\section{Photothermal conversion efficiency determined from the time constant}

The changes of temperature in the solution with PtAu NRs irradiated by $650 \mathrm{~nm}$ and $808 \mathrm{~nm}$ lasers, were investigated to determine the efficiency of the photothermal conversion (Fig. 8).

A temperature increase of $5.8^{\circ} \mathrm{C}$ in the PtAu NRs solution was observed for the $650 \mathrm{~nm}$ laser (Fig. 8, orange line), which is higher than for the $808 \mathrm{~nm}$ laser $\left(4.8^{\circ} \mathrm{C}\right)$ (Fig. 8, red line). The smallest increase of temperature was noticed for the control solution: only $1.3^{\circ} \mathrm{C}$.

Moreover, the calculated photothermal conversion efficiency showed that the value of $\eta$ is higher for the
$650 \mathrm{~nm}$ laser than for the $808 \mathrm{~nm}$ laser, being $62 \%$ and $51 \%$, respectively. Furthermore, the highest value (72\%) of photothermal efficiency of nanoparticles was obtained for the $650 \mathrm{~nm}$ laser. For the laser with the $808 \mathrm{~nm}$ wavelength $\eta_{\mathrm{NRs}}$ is $12 \%$ lower, than for the $650 \mathrm{~nm}$ laser.

\section{Discussion}

High extinction coefficients of Au NPs and Pt NPs in the NIR region make the core/shell nanoraspberries attractive candidates to be used in photothermal therapy [13]. However, the cytotoxicity of platinum itself is quite high, so its surface has to be modified or combined with substances, which are biocompatible [42]. Fortunately, gold 


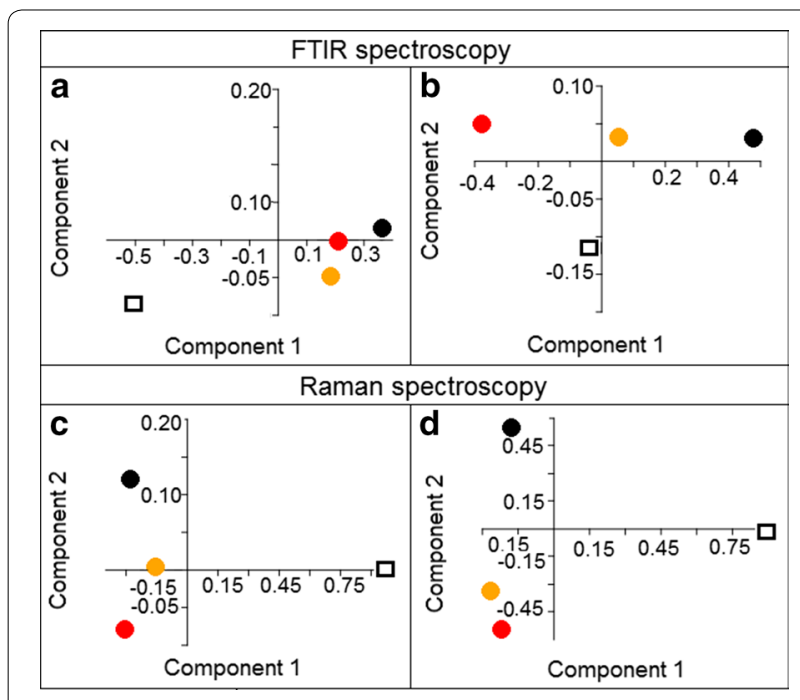

Fig. 6 PCA analysis of FTIR and Raman spectra of: SW480 (a and c, respectively) and SW620 (b and d, respectively) cell lines. PCA was performed based on the selected spectral FTIR and Raman regions: between 800 and $1800 \mathrm{~cm}^{-1}$. The different colors of dots correspond to following samples: control (hollow squares); cells cultured with PtAu NRs (black dots); cells cultured with PtAu NRs and irradiated by the $650 \mathrm{~nm}$ light (orange dots); cells cultured with PtAu NRs and irradiated by the $808 \mathrm{~nm}$ wavelength (red dots)

has not only excellent photothermal properties, it is also a metal exhibiting a low cytotoxic effect [43, 44]. Herein, a combination of Pt NPs and Au NPs is created by synthesizing Au NPs on Pt NPs forming PtAu NRs, to show their light-absorbing properties in the biological near-infrared window.

STEM HAADF images (Fig. 1a) with the EDX maps (Fig. 1b) showed that larger Pt NPs are surrounded by a dozen of Au NPs. Due to this fact the interaction of the more cytotoxic Pt NPs with cells is hindered. Moreover, the SAED and XRD patterns (Fig. 2) showed that the PtAu NRs have a crystalline fcc structure. The cytotoxic effect of the nanoparticles depends on their crystallinity, because the photocatalytic activity of NPs is directly proportional to the availability of active sites and not to the total surface area of the NPs [45]. For amorphous NPs, a higher cytotoxic effect was observed, therefore for biological applications it is very important that the nanoparticles are crystalline like it is the case of the investigated PtAu NRs [46]. However, after irradiation, a high mortality of cancer cells cultured with PtAu NRs, was observed, in contrast to irradiated cells, cultured however without the nanoraspberries (Fig. 7). These results were also confirmed by the microscopy images of cells with PtAu NRs subjected to irradiation (Fig. 3), showing cells peeled off from the support, indicating their death. It was caused by the increase of temperature in the cancer cells, which was induced by the laser irradiation of the PtAu NRs present in the cell culture. Cancer cells are more sensitive to high temperature than healthy cells. High temperatures during laser irradiation, which are generated by the presence

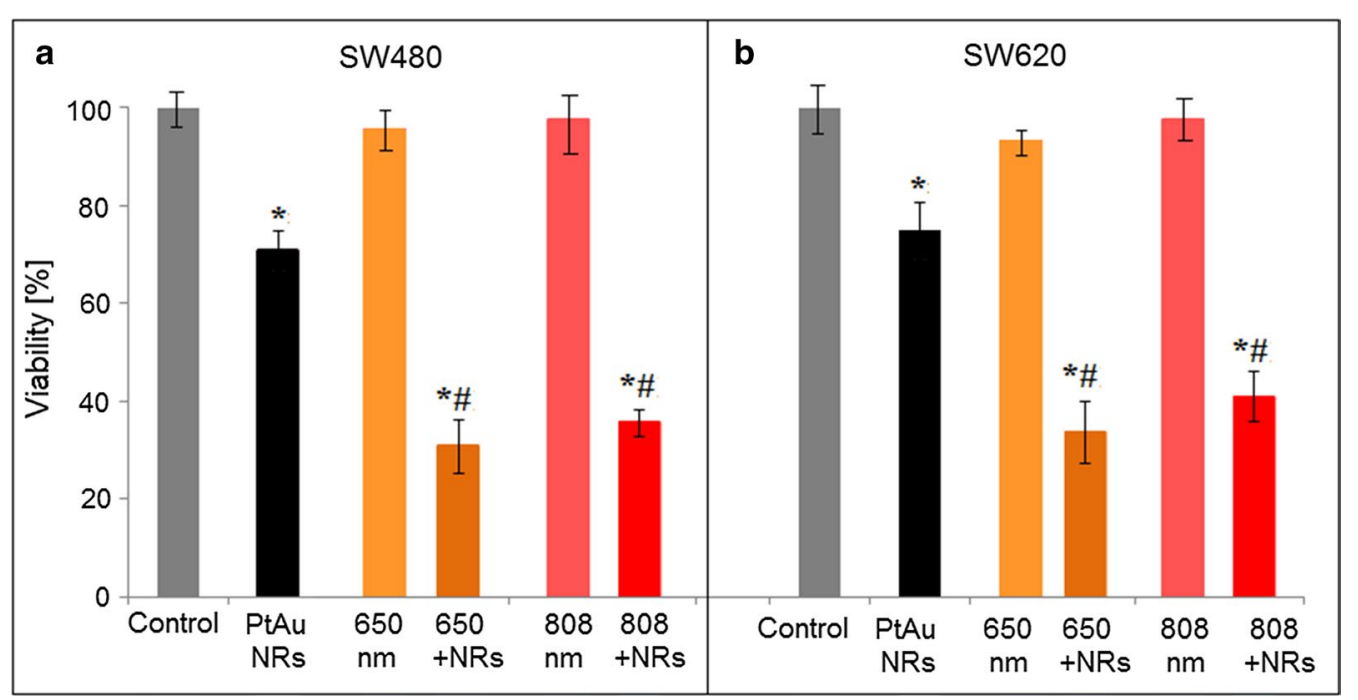

Fig. 7 Viability of colon cancer cells: SW480 and SW620 after addition of PtAu NRs and after laser irradiation with and without PtAu NRs. Data was considered as significant when ${ }^{*} p<0.05$ vs. control; ${ }^{*} p<0.05$ vs. PtAu NRs. Grey color—control samples; black color — cells cultured with PtAu NRs; bright orange_cells irradiated by the $650 \mathrm{~nm}$ laser during $5 \mathrm{~min}$; dark orange_cells cultured with PtAu NRs and irradiated by the $650 \mathrm{~nm}$ laser during 5 min; bright red_cells irradiated by the $808 \mathrm{~nm}$ laser during 5 min; dark red_cells cultured with PtAu NRs and irradiated by the $808 \mathrm{~nm}$ laser during $5 \mathrm{~min}$ 


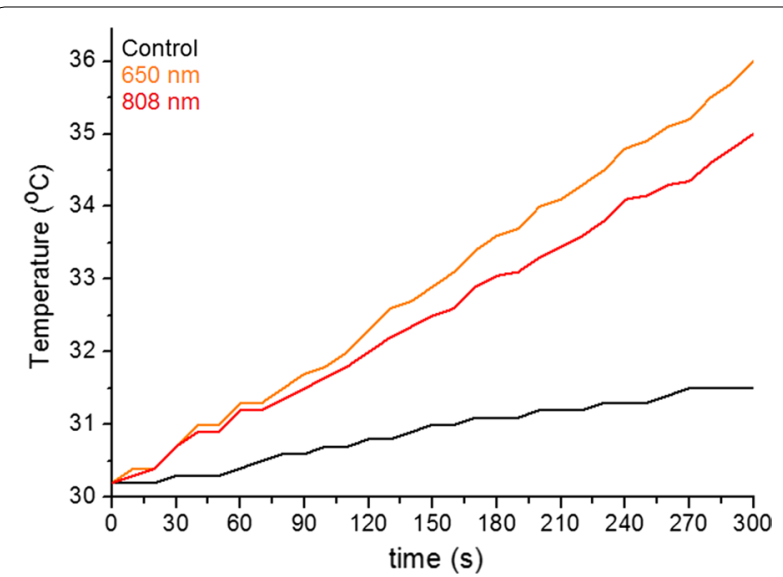

Fig. 8 Temperature changes in PtAu NRs solutions during 5 min irradiation by the $650 \mathrm{~nm}$ (red line) and the $808 \mathrm{~nm}$ (orange line) lasers. The black line corresponds to the water (control) solution

of PtAu NRs (Fig. 8) in cancer cells, lead to necrosis or apoptosis of the latter ones, while in normal cells these high temperatures did not cause significant changes [47-49]. Moreover, the PtAu NRs have high values of photothermal conversion efficiency in the electromagnetic range corresponding to biological near-infrared windows. Shang et al. showed a $70 \%$ mortality of cancer cells after $150 \mathrm{~s}$ irradiation by an $808 \mathrm{~nm}$ laser with addition of $\mathrm{Au}-\mathrm{Pt} \mathrm{NPs}$ [50]. However, they used a laser with ten times higher power, than the one in the present work. Moreover, the Au-Pt NPs synthesized by Shang et al. were composed of larger Au NPs, which were surrounded by more cytotoxic Pt NPs. Furthermore, smaller Pt NPs exhibit a higher active surface, which plays a crucial role in anticancer properties [51].

FTIR (Fig. 4) and FT-Raman (Fig. 6) spectra of cells cultured with PtAu NRs showed that laser irradiation caused chemical changes in the structure of DNA, RNA and phospholipids, which could mean necrosis of cancer cells. Necrosis is characterized by loss of plasma membrane integrity, and the cell membrane consists mainly of phospholipids [52]. Moreover, the laser irradiation effect can trigger detrimental inflammatory and immunogenic responses, inducing necrosis or other kind of cell death [53]. Furthermore, the spectra showed chemical changes in the protein and lipid structures of cancer cells. The high temperature observed due to laser irradiation in the presence of PtAu NRs, caused the protein denaturation [7]. As a result of this process, changes in the structure and function of these chemical compounds, were induced. In FTIR (Fig. 4) and FT-Raman (Fig. 6) spectra of cells cultured with $\mathrm{PtAu}$ NRs, also changes in the protein structure were visible. These can be caused by platinum, which has enzymatic properties and can change the functionality of chemical structures building the cells [54].

Summarizing, the synthesized PtAu NRs have a crystalline structure, which caused a decrease of the cytotoxic effect on cancer cells. High values of nanoparticles photothermal efficiency, $72 \%$ for the $650 \mathrm{~nm}$ laser and $60 \%$ for the laser with $808 \mathrm{~nm}$ wavelength, suggest that these nanoparticles could be applied as effective light-absorbers in the PTT anticancer therapy.

\section{Supplementary information}

Supplementary information accompanies this paper at https://doi. org/10.1186/s12951-019-0539-2.

Additional file 1: Figure S1. Viability of colon cancer cells: SW480 (a) and SW620 (b) after irradiation by $650 \mathrm{~nm}$ and $808 \mathrm{~nm}$ lasers during 5, 10 and $15 \mathrm{~min}$. Data was considered as significant when ${ }^{*} p<0.05$ vs. Control samples.

\section{Acknowledgements}

KB acknowledges the support of InterDokMed project no. POWR.03.02.0000-I013/16. Dr. Ewa Juszyńska-Gałązka from the Department of Soft Matter Research, Institute of Nuclear Physics Polish Academy of Sciences, is acknowledged for her help in FTIR measurements. Dr. Monika Kula is acknowledged for the use of the Raman instrument located at Polish Academy of Sciences, The Franciszek Górski Institute of. Partial financial support by Pik-Instruments is greatly acknowledged. Many thanks also to the Department of Chemistry, University of Warsaw, for the access to the Talos F200 FEI TEM instrument purchased by Biological and Chemical Research Centre, University of Warsaw, established within the project co-financed by European Union from the European Regional Development Fund under the Operational Program Innovative Economy, 2007-2013.

\section{Authors' contributions}

$J \mathrm{D}$ and JB conceived and designed the study. JD, BK and MS performed the experiments, JD and MP-W analyzed and interpreted the data and wrote the manuscript. All authors read and approved the final manuscript.

\section{Funding}

This work was not financially supported.

\section{Availability of data and materials}

All data generated or analyzed during this study are included in this published article and its additional information files.

Ethics approval and consent to participate

The research was done in accordance with the principles of ethics.

\section{Consent for publication}

All authors agreed to submit this manuscript.

\section{Competing interests}

The authors declare that they have no competing interests.

\section{Author details}

${ }^{1}$ Institute of Nuclear Physics Polish Academy of Sciences, 31-342 Krakow, Poland. ${ }^{2}$ Department of Clinical Immunology, Institute of Pediatrics, Jagiellonian University Medical College, 30-663 Krakow, Poland.

Received: 12 June 2019 Accepted: 9 October 2019

Published online: 15 October 2019 


\section{References}

1. Woźniak A, Malankowska A, Nowaczyk G, Grześkowiak BF, Tuśnio K, Słomski R, et al. Size and shape-dependent cytotoxicity profile of gold nanoparticles for biomedical applications. J Mater Sci Mater Med. 2017;28(6):92

2. Zhang L, Gu FX, Chan JM, Wang AZ, Langer RS, Farokhzad OC. Nanoparticles in medicine: therapeutic applications and developments. Clin Pharmacol Ther. 2008;83(5):761-9.

3. Klebowski B, Depciuch J, Parlinska-Wojtan M, Baran J. Applications of noble metal-based nanoparticles in medicine. Int J Mol Sci. 2018;19(12):4031.

4. Brun E, Sicard-Roselli C. Actual questions raised by nanoparticle radiosensitization. Radiat Phys Chem. 2016;128:134-42.

5. Hamblin MR, Chiang LY, Lakshmanan S, Huang YY, Garcia-Diaz M, et al. Nanotechnology for photodynamic therapy: a perspective from the laboratory of Dr. Michael R. Hamblin in the Wellman Center for Photomedicine at Massachusetts General Hospital and Harvard Medical School. Nanotechnol Rev. 2015:4(4):359-72.

6. Malemed JR, Edelstein RS, Day ES. Elucidating the fundamental mechanism of cell death triggered by photothermal therapy. ACS Nano. 2015;9(1):6-11.

7. Riley RS, Day ES. Gold nanoparticle-mediated photothermal therapy: applications and opportunities for multimodal cancer treatment. Wiley Interdiscip Rev Nanomed Nanobiotechnol. 2017. https://doi.org/10.1002/ wnan.1449.

8. Ali HS, Ahmed S, Khan GA. Gold nanoparticles in cancer therapy and diagnostics. Eur J Pharm Med Res. 2016:3(2):54-67.

9. Farooq MU, Novosad V, Rozhkova EA, Wali H, Ali A, Fated AA, et al. Gold nanoparticles-enabled efficient dual delivery to anticancer therapeutics to HeLa cells. Sci Rep. 2018;8:2907.

10. Porcel E, Liehn S, Remita H, Usami N, Kobayashi K, Furusawa Y, et al. Platinum nanoparticles: a promising material for future cancer therapy? Nanotechnology. 2010;21(8):85103.

11. Jain PK, Huang X, El-Sayed IH, El-Sayed MA. Noble metals on the nanoscale: optical and photothermal properties and some applications in imaging, sensing, biology and medicine. Acc Chem Res. 2008;41(12):1578-86.

12. Huang $X$, El-Sayed MA. Gold nanoparticles: optical properties and implementations in diagnosis and photothermal therapy. J Adv Res. 2010;1(1):13-28.

13. Dumas A, Couvreur P. Palladium: a future key player in the nanomedical field? Chem Sci. 2015:6(4):2153-7.

14. Pfaller T, Colognato R, Nelissen I, Favilli F, Casals E, Ooms D, et al. The suitability of different cellular in vitro immunotoxicity and genotoxicity methods for the analysis of nanoparticle-induced events. Nanotoxicology. 2010;4(1):52-72.

15. Miller MR, Raftis JB, Langrish JP, McLean SG, Samutrtrai P, Connell SP. Inhaled nanoparticles accumulate at sites of vascular disease. ACS Nano. 2017:11(5):4542-52.

16. Adil SF, Assal ME, Khan M, Al-Warthan A, Siddiqui MRH, Liz-Marzan LM Biogenic synthesis of metallic nanoparticles and prospects toward green chemistry. Dalton Trans. 2015;44:9707-17.

17. Schmid G, Kreyling WG, Simon U. Toxic efects and biodistribution of ultrasmall gold nanoparticles. Arch Toxicol. 2017;91(9):3011-37.

18. Rodriguez-Carvajal. Introduction to the program FULLPROF: refinement of crystal and magnetic structures from powder and single crystal data. Tech Report CEA-CNRS Saclar Fr. 1990.

19. Thompson $\mathrm{P}, \mathrm{Cox} D E$, Hastings JB. Rietveld refinement of Debye-Scherrer synchrotron x-ray data from $\mathrm{Al}_{2} \mathrm{O}_{3}$. J Appl Crystallogr. 1987;20:79-83.

20. Shim K, Lee WC, Heo YU, Shahubuddin M, Park MS, Hossain MSA, et al. Rationally designed bimetallic Au@Pt nanoparticles for glucose oxidation. Sci Rep. 2019;9(1):894

21. Devi S, Singh B, Paul AK, Tyagi S. Highly sensitive and selective detection of trinitrotoluene using cysteine-capped gold nanoparticles. Anal Methods. 2016:8:4398-405

22. Sen F, Karatas Y, Gulcan M, Zahmakiran M. Amylamine stabilized platinum(0) nanoparticles: active and reusable nanocatalyst in the room temperature dehydrogenation of dimethylamine-borane. RSC Adv. 2014:4:1526-31.
23. Jurkiewicz K, Kaminski M, Glajcar W, Woznica N, Julienne F, Bartczak P, et al. Paracrystalline structure of gold, silver, palladium and platinum nanoparticles. J Appl Crystallogr. 2018;51(2):411-9.

24. Leontyev IN, Kuriganova AB, Leontyev NG, Hennet $L$, Rakhmatullin A, Smirnova NV, et al. Size dependence on the lattice parameters of carbon supported platinum nanoparticles: X-ray diffraction analysis and theoretical considerations. RSV Adv. 2014;4:35959-65.

25. Kwon K, Lee KY, Lee YW, Kim M, Heo J, Ahn SJ, et al. Controlled synthesis of icosahedral gold nanoparticles and their surface-enhanced Raman scattering property. J Phys Chem C. 2007;111(3):1161-5.

26. Maziak DE, Do MT, Shamji FM, Sundaresan SR, Perkins DG, Wong PT. Fourier-transform infrared spectroscopic study of characteristic molecular structure in cancer cells of esophagus: an exploratory study. Cancer Detect Prev. 2007;31(3):244-53.

27. Krishna CM, Sockalingum GD, Bhat RA, Venteo L, Kushtagi P, Pluot M, et al. FTIR and Raman microspectroscopy of normal, benign, and malignant formalin-fixed ovarian tissues. Anal Bioanal Chem. 2007;387(5):1649-56.

28. Movasaghi Z, Rehman S, ur Rehman I. Fourier transform infrared (FTIR) spectroscopy of biological tissues. Appl Spectrosc Rev. 2008;43(2):134-79.

29. Elmi F, Movaghar AF, Elmi MM, Alinezhad H, Nikbakhsh N. Application of FT-IR spectroscopy on breast cancer serum analysis. Spectrochim Acta A Mol Biomol Spectrosc. 2017;187:87-91.

30. Yano K, Okoshima S, Gotou Y, Kumaido K, Moriguchi T, Katayama H. Direct measurement of human lung cancerous and noncancerous tissues by fourier transform infrared microscopy: can an infrared microscope be used as clinical tool? Anal Biochem. 2000;287(2):218-25.

31. Barth A, Zscherp C. What vibrations tell us about proteins. Q Rev Biophys. 2002;35(4):369-430.

32. Wrobel PT, Mateuszuk L, Chlopicki S, Malek K, Baranska M. Imaging of lipids in atherosclerotic lesion in aorta from ApoE/LDLR-/- mice by FT-IR spectroscopy and hierarchical cluster analysis. Analyst. 2011;136(24):5247-55.

33. Barth A. Infrared spectroscopy of proteins. Biochim Biophys Acta. 2007;1767(9):1073-101.

34. Chan JW, Taylor DS, Zwerdling T, Lane SM, Ihara K, Huser T. Micro-Raman spectroscopy detects individual neoplastic and normal hematopoietic cells. Biophys J. 2006;90(2):648-56.

35. Krafft C, Neudert L, Simat T, Salzer R. Near infrared Raman spectra of human brain lipids. Spectrochim Acta A Mol Biomol SpectrosC 2005:61(7):1529-35.

36. Silveira L Jr, Sathaiah S, Zangaro RA, Pacheco MT, Chavantes MC, Pasqualucci CA. Correlation between near-infrared Raman spectroscopy and the histopathological analysis of atherosclerosis in human coronary arteries. Lasers Surg Med. 2002;30(4):290-7.

37. Stone N, Kendall C, Smith J, Crow P, Barr H. Raman spectroscopy for identification of epithelial cancers. Faraday Discuss. 2004:126:141-57.

38. Huang Z, McWilliams A, Lui H, McLean DI, Lam S, Zeng H. Near-infrared Raman spectroscopy for optical diagnosis of lung cancer. Int J Cancer. 2003:107(6):1047-52.

39. Huang Z, McWilliams A, Lam S, English J, McLean DI, Lui H, et al. Effect of formalin fixation on the near-infrared Raman spectroscopy of normal and cancerous human bronchial tissues. Int J Oncol. 2003;23(3):649-55.

40. Stremersch S, Marro M, Pinchasik BE, Baatsen P. Hendrix A de Smedt SC, et al. Identification of individual exosome-like vesicles by surface enhanced Raman spectroscopy. Small. 2016;12(24):3292-301.

41. Malini R, Venkatakrishna K, Kurien J, Pai KM, Rao L, Kartha VB, et al. Discrimination of normal, inflammatory, premalignant, and malignant oral tissue: a Raman spectroscopy study. Biopolymers. 2006:81(3):179-93.

42. Bendale $Y$, Bendale V, Paul S. Evaluation of cytotoxic activity of platinum nanoparticles against normal and cancer cells and its anticancer potential through induction of apoptosis. Integr Med Res. 2017;6(2):141-8.

43. Kim ST, Saha K, Kim C, Rotello VM. The role of surface functionality in determining nanoparticle cytotoxicity. Acc Chem Res. 2013;46(3):681-91.

44. Tagami T, Taki M, Ozeki T. Nanomaterials in pharmacology. Methods Pharmacol Toxicol. 2016:39:333-47.

45. Sclafani A, Herrmann JM. Comparison of the photoelectronic and photocatalytic activities of various anatase and rutile forms of titania in pure liquid organic phases and in aqueous solutions. J Phys Chem. 1996;100(32):13655-61. 
46. Jiang J, Oberdorster G, Elder A, Gelein R, Mercer P, Biswas P. Does nanoparticle activity depend upon size and crystal phase? Nanotoxicology. 2008;2(1):33-42.

47. Perez-Hernandez M, Del Pino P, Mitchell SG, Moros M, Stepien G, Pelaz B et al. Dissecting the molecular mechanism of apoptosis during photothermal therapy using gold nanoprisms. ACS Nano. 2015;9(1):52-61.

48. Huang $X$, Jain PK, El-Sayed IH, El-Sayed MA. Determination of the minimum temperature required for selective photothermal destruction of cancer cells with the use of immunotargeted gold nanoparticles. Photochem Photobiol. 2006;82(2):412-7.

49. Ali MR, Rahman MA, Wu Y, Han T, Peng X, Mackey MA, et al. Efficacy, long-term toxicity, and mechanistic studies of gold nanorods photothermal therapy of cancer in xenograft mice. Proc Natl Acad Sci USA. 2017;114(15):E3110-8.

50. Song Y, Shi Q, Zhu C, Luo Y, Lu Q, Li H, et al. Mitochondrial-targeted multifunctional mesoporous Au@Pt nanoparticles for dual-mode photodynamic and photothermal therapy of cancers. Nanoscale. 2017;9(41):15813-24.
51. Shang L, Nienhaus K, Nienhaus GU. Engineered nanoparticles interacting with cells: size matters. J Nanobiotechnol. 2014;12:5.

52. Greenberg ME, Li XM, Gugiu BG, Gu X, Qin J, Salomon RG, Hazen SL. The lipid whisher model of the structure of oxidized cell membranes. J Biol Chem. 2008;283(4):2385-96.

53. Martin SJ, Henry CM, Cullen SP. A perspective on mammalian caspases as positive and negative regulators of inflammation. Moll Cell. 2012;46(4):387-97.

54. Pedone D, Moglianetti M, De Luca E, Bardi G, Pompa PP. Platinum nanoparticles in nanobiomedicine. Chem Soc Rev. 2017;46(16):4951-75.

\section{Publisher's Note}

Springer Nature remains neutral with regard to jurisdictional claims in published maps and institutional affiliations.
Ready to submit your research? Choose BMC and benefit from:

- fast, convenient online submission

- thorough peer review by experienced researchers in your field

- rapid publication on acceptance

- support for research data, including large and complex data types

- gold Open Access which fosters wider collaboration and increased citations

- maximum visibility for your research: over $100 \mathrm{M}$ website views per year

At BMC, research is always in progress.

Learn more biomedcentral.com/submissions 